\title{
Detection of the Hyaluronan Receptor CD44 in the Bovine Oviductal Epithelium
}

\section{Ann-Sofi BERGQVIST ${ }^{1)}$, Masaki YOKOO ${ }^{2)}$, Renée BÅGE'), Eimei SATO') and Heriberto RODRÍGUEZ-MARTíNEZ1)}

1)Division of Comparative Reproduction, Obstetrics and Udder Health, Faculty of Veterinary Medicine and Animal Science, Swedish University of Agricultural Sciences, SLU, Uppsala, Sweden, Centre for Reproductive Biology in Uppsala, CRU, Sweden, ${ }^{2}$ Laboratory of Animal Reproduction, Graduate School of Agricultural Science, Tohoku University, Sendai, Japan

\begin{abstract}
Hyaluronan is involved in fundamental reproductive events such as sperm storage in the female reproductive tract, fertilization, and early embryo development, these functions are presumably mediated by its major cell surface receptor, CD44. The present study was conducted to investigate the presence and localization of CD44 in the bovine oviductal epithelium, using immunohistochemical and Western blot methods on tissue sections and epithelial cell extracts collected from the uterotubal junction (UTJ), isthmus, and ampulla of animals in the oestrus or luteal phase of the oestrous cycle. While positive immunolabelling for CD44 was found on the ad-luminal surface and supra-nuclear region of epithelial cells in all tubal segments investigated, in the UTJ, there were epithelial cells in which the entire cytoplasm positively stained. We found no differences in terms of CD44-positive staining between the different stages of the oestrous cycle. Presence of CD44 was detected by Western blotting in the tubal epithelium as a single band at $200 \mathrm{kDa}$. Although it appeared in all tubal segments, the expression of CD44 protein was more accentuated in the sperm reservoir (UTJ) than in the other segments. This is the first time CD44 has been detected in the epithelium of the tubal sperm reservoir in cattle, suggesting a pathway for the action of hyaluronan in this segment.
\end{abstract}

Key words: CD44, Hyaluronan, Bovine, Oviduct

(J. Reprod. Dev. 51: 445-453, 2005)

H yaluronan (HA) is a glycosaminoglycan (GAG) present in the majority of interstitial spaces and basal membranes of the epithelia, particularly in those cells under proliferation [1], including those of the bovine female genital tract [2]. HA carries out its biological functions through interactions via HA-binding proteins (HABPs) referred to as hyaladherins [3]. Among the specific transmembrane receptors for HA, such as CD44 [4],

Accepted for publication: April 14, 2005

Published online: April 22, 2005

Correspondence: A-S. Bergqvist (e-mail: ann-sofi.bergqvist@kv. slu.se)
RHAMM, and PH-20 $[5,6]$. CD44 is the most widely distributed cell-surface protein [7] and is thus considered the main ligand for HA [8].

The CD44 receptor participates in a wide variety of cellular functions such as cell proliferation, migration and differentiation, cell-cell and cellmatrix adhesion, uptake and degradation of HA, development and morphogenesis, tumour progression, inhibition of apoptosis and immune response [4, 9-15]. Recently, CD44-HA interactions have emerged as important in cell signalling [16]. Various isoforms of CD44 have been detected in human cervical epithelium [11] endometrium [13, 
17, 18], follicular fluid [19], placenta [20-22], oocytes and early embryos [23].

During oocyte maturation and cumulus expansion, cumulus cells produce HA in cows [24, 25], pigs [26-28], mice [29], and humans [30]. Some of these studies also found that the CD44 receptors in the cumulus cells were upgraded during oocyte maturation.

Some HABPs have been found on the spermatozoa of bulls and of other mammalian species [31]. Shortly after mating or artificial insemination, spermatozoa colonize the UTJ, an area that includes the final portion of the uterus and the first portion of the adjacent caudal isthmus, considered as the tubal sperm reservoir, before they are released towards the site of fertilization [32-34]. In the sperm reservoir, the male gametes are in contact with the oviductal epithelium and the mucoid tubal fluid, which is rich in GAGs [2]. Bull spermatozoa are able to keep their viability and fertilizing capacity while stored in the sperm reservoir [35]. The sperm reservoir also seems to prevent the process of sperm capacitation, possibly through the process of sperm binding to the epithelium in vitro in cows [36] and in pigs [37]. In addition, the sperm reservoir controls the progression of suitable spermatozoa, in very restricted numbers, to the site of fertilization of the newly ovulated oocytes [32, 34, 38]. Moreover, various GAGs have been found to be able to maintain sperm motility and induce capacitation in vitro in bovine [39] and other species [40-42].

Additionally, our group has been able to demonstrate the presence of HA in epithelial cells from well-defined segments of the oviduct from cattle and pigs $[43,44]$. As well, CD44 was detected in the porcine oviduct, with the strongest expression in the pre-ovulatory sperm reservoir [45]. CD44 has been found in human spermatozoa [46], and CD44 has also recently been detected in the spermatozoa of the bull [Bergqvist et al., unpublished data]. In sum, the above information may indicate a pathway system including HA, CD44, and other HABPs in regions of the female genital tract and on gametes and vestments. The system may be involved in gamete function, including during sperm transport, fertilization, and embryo development.

The aim of the present study was to investigate the presence and localization of the hyaluronan receptor CD44 in the epithelium of well-defined functional segments of the bovine oviduct during the oestrous cycle.

\section{Materials and Methods}

\section{Animals, tissue collection, and preparation}

Oviductal tissue was retrieved either surgically or post-mortem from a total of 26 bovines. Thirteen (13) of the animals were Swedish Red and White (SRB) dairy heifers sampled during standing oestrus. The remaining 13 specimens were Swedish dairy cows and heifers of various breeds slaughtered at a local abattoir in the luteal phase of the oestrous cycle (metaoestrous $=3$, dioestrous $=10$ ). The oestrous cycles of the SRB heifers were followed for at least 6 mo prior to collection, through observation for signs of spontaneous oestrous and through gynaecological examination by transrectal palpation and ultrasonography of the ovaries and uterus, which included visualisation of the occurrence of spontaneous ovulation thus ensuring proper cycle stage monitoring. The oviducts were either retrieved by flank laparotomy as described by Duchens et al. [47] or collected postmortem from the heifers in spontaneous oestrus. This operation and the euthanasia of the heifers took place $4 \mathrm{~h}$ after onset of standing oestrus. Thus, tissue retrieval occurred before the expected $\mathrm{LH}$ surge. After collection, the oviducts were properly divided into isthmus (I), ampulla (A), and uterotubal junction (UTJ), segments, and immersion fixed in a $1-4 \%$ solution of paraformaldehyde (PFA) in $0.15 \mathrm{M}$ PBS for immunohistochemical investigation. These specimens were stored at $4 \mathrm{C}$ until being embedded in paraffin using standard procedures, sectioned in $4-\mu \mathrm{m}$ thick sections, and mounted on polylysinecoated glass slides. Samples for protein extraction were taken from 5 of the same SRB heifers in standing oestrus, and the contra-lateral oviducts were divided into the same three functional regions (I, A, and UTJ) and immediately deep-frozen in liquid nitrogen.

The Ethical Committee for Experimentation with Animals, Uppsala, Sweden, approved the experimental protocol in advance of the study.

\section{Immunohistochemistry}

The sections were de-paraffinised and rehydrated using xylene and ethanol. After 
washing in tap water, immersion in $3 \% \mathrm{H}_{2} \mathrm{O}_{2}$ in methanol for 5 min was used to block endogenous peroxidase activity. The slides were rinsed in PBS ( $\mathrm{pH}$ 7.4). The same PBS was used to dilute all antibodies, blocking and detecting agents, including all intermediate washes between incubation steps. Optimal fixation, dilutions, incubation times, and pre-treatments were established in preliminary studies. To avoid nonspecific binding, the slides were blocked for 20 min with BSA $(5 \mathrm{mg} / \mathrm{mL})$ before the primary CD44 antibody (biotinylated KM201; $5 \mu \mathrm{g} / \mathrm{mL}$; Biosource International, Camarillo, CA, USA,) was applied and the slides were incubated overnight at $4 \mathrm{C}$ in a humidity chamber. Following washing, sections were incubated for $40 \mathrm{~min}$ in avidin-biotinperoxidase (1:250; Vectastain ABC-Elite standard; Vector Laboratories, Burlingame, CA, USA). Sections were rinsed again and developed in the substrate 3,3'-diaminobenzidine (DAB; DAKO, Glostrup, Denmark) with $3 \% \mathrm{H}_{2} \mathrm{O}_{2}$. Slides were counterstained with haematoxylin and finally mounted. To check the specificity of the secondary antibodies, the primary antibodies were replaced with PBS. As negative controls, duplicates of all sections were reacted with biotinylated rat IgG1 kappa ( $5 \mu \mathrm{g} / \mathrm{mL}$; BD Pharmingen, San Diego, CA, USA) instead of primary antibody. Bovine leukocytes were used as positive controls.

\section{Preparation of oviductal epithelium cell extracts for protein detection}

The UTJ and I segments were cut open and the lining epithelium was scraped using the blunt side of a scalpel blade. The epithelial cells from the A segment were obtained by squeezing the segment from the outside with a forceps and "milking" the extruded contents. This method has proven in our laboratory to give a sufficient amount of uncontaminated oviductal epithelial cells [45].

The retrieved oviductal epithelial cells were vortexed in 10-fold volume-to-volume of protein extraction buffer containing $50 \mathrm{mM}$ Tris- $\mathrm{HCl}(\mathrm{pH}$ 7.5), 1 mM PMSF, 0.1 M 6-amno-hexanoic acid, 5 $\mathrm{mM}$ benzamidine $\mathrm{HCl}$, and $1 \%$ CHAPS, and then stirred in the same buffer at $4 \mathrm{C}$ for $1 \mathrm{~h}$. The extract was centrifuged at $15,000 \mathrm{rpm}$ for $30 \mathrm{~min}$ at $4 \mathrm{C}$ and the supernatant was removed. Protein concentrations were measured using bovine gamma globulin as a standard (RC DC Protein Assay Kit I, Bio-Rad Laboratories, Hercules, CA,
USA), according to manufacturer's instructions.

\section{Detection of protein}

Extracted proteins (20 $\mu \mathrm{g}$ per lane) were separated by $7.5 \%$ SDS-PAGE under non-reducing conditions and electroblotted onto PVDF membranes (Millipore, Bedford, MA, USA) in a semi-dry blotting apparatus according to the method of Hirano and Watanabe [48]. Electroblotting was performed for $90 \mathrm{~min}$ at a constant current of $0.8 \mathrm{~mA} / \mathrm{cm}^{2}$. After electroblotting, the membranes were washed with PBS-T $(0.05 \%$ [v/v] Tween 20, pH 7.4).

Instead of being electroblotted to PVDF membranes, corresponding SDS-PAGE gels were stained with Coomasie brilliant blue to check the distribution of total proteins in the oviductal epithelial cells.

For Western blotting, the PVDF membranes were blocked with $2 \%$ skimmed milk in PBS-T overnight at room temperature and washed 3 times with PBST. The membranes were incubated with the primary antibody anti-mouse CD44 $(1 \mu \mathrm{g} / \mathrm{mL}$; KM201; Wako, Osaka, Japan), for $1 \mathrm{~h}$ at room temperature, and then reacted with horseradish peroxidase-conjugated secondary antibody diluted 1:1000. After washing three times with PBS-T, the peroxidase activity was visualized using the ECL Western blotting detection system (Amersham, Alington Heights, IL, USA) according to the manufacturer's instructions.

\section{Results}

\section{Immunohistochemistry}

Control slides, incubated with biotinylated rat IgG or PBS instead of the primary biotinylated CD44 antibody, were negative (Figs. 1a and 1b, respectively). As expected, bovine leukocytes showed positive immunostaining for CD44 in the cell cytoplasm and surface (Figs. 1c).

Positive CD44 immunolabelling was present along the tubal epithelium. No differences in immunolabelling were detected when using the different PFA concentrations hereby tested (1-4\%). The intensity of immunolabelling, as seen with the light microscope, varied from weak to strong staining on the epithelial ad-luminal surface as well as in the supra-nuclear region of scattered epithelial cells. In the UTJ segment, some epithelial cells 

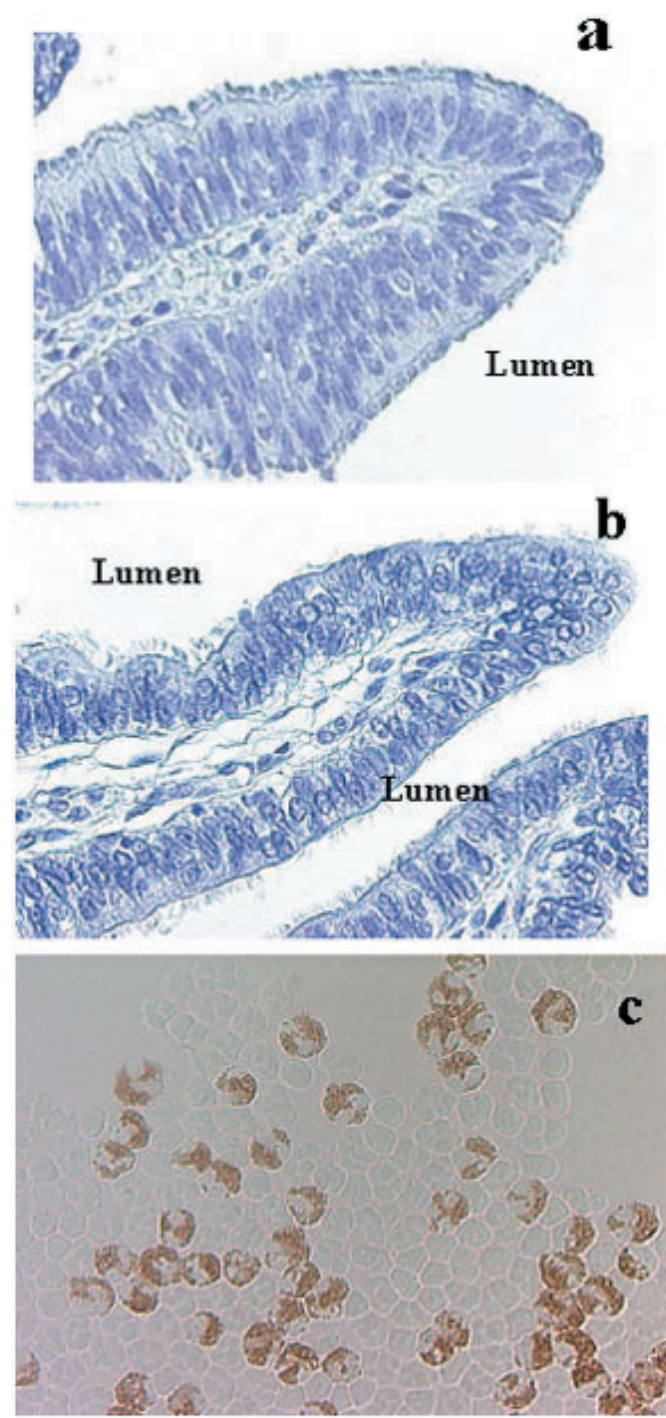

Fig. 1 a-c. Control sections. a-b: Negative controls. Microphotographs of sections from the bovine oviductal ampulla. The primary CD44 antibody was replaced with either biotinylated rat IgG (a) or PBS (b). The slides are counterstained with haematoxylin, $\times 200$. c: Positive control. Microphotographs of bovine leukocytes showing immunostaining for CD44 in the cytoplasm and on the surface of the cells, $\times 600$.

seemed positively stained throughout the entire cytoplasm (Figs. 2a and 2b), whereas in the isthmic (Figs. 2c and 2d) and ampullar (Figs. 2e and 2f) segments the immunostaining was restricted to the supra-nuclear region of the cytoplasm. The cytoplasmic positive immunolabelling included both ciliated and non-ciliated (i.e. secretory) epithelial cells, irrespective of the tubal segment considered (Figs. 2a-f, arrows). There were no differences in terms of immunostaining of the bovine tubal epithelium among the 3 different stages (oestrus, dioestrus, and metoestrus) investigated (Figs. 2a-f).

Immunopositive connective tissue cells were present in all slides, most conspicuously stained in the lamina propria of the ampullar segment (Figs. 2e and 2f). As well, CD44 immunostaining was present in the leukocyte-like cells in the epithelium and lamina propria along the tubal segments studied.

\section{Western blotting}

Using KM201, a band at $200 \mathrm{kDa}$ was detected in all oviductal samples, with a relatively higher intensity in the UTJ segment, compared to the other segments of the bovine oviduct, although a difference among different individuals was seen (Fig. 3).

\section{Discussion}

The present study demonstrates for the first time that the main hyaluronan receptor, CD44, is present in bovine oviductal epithelial cells during spontaneous oestrus, being particularly evident in the uterotubal junction (UTJ) segment, the major part of the functional sperm reservoir in the female. This immuno- and Western blot localization is in line with the localization found in pigs [45] indicating that a general receptor-ligand system might be present in ungulates.

A signalling response to HA may be strongly influenced by both the size of HA and the cell background [16]. Presence of HA has been demonstrated in the female genitalia of mice [49] and humans [50], and in oviductal epithelial cells in cattle and pigs [43, 44]. In a preliminary study (Bergqvist et al., unpublished data), seven bands of HABP were detected in protein samples from bovine oviductal epithelial cells. Among these, the UTJ segment sample had a band at $200 \mathrm{kDa}$ of relatively higher intensity than was the case with samples from the isthmus or the ampulla. We speculate that this $200 \mathrm{kDa} \mathrm{HABP}$ is the same as the CD44 found at $200 \mathrm{kDa}$.

The versatility of CD44 function shown in the literature is assumed to result from a multitude of 


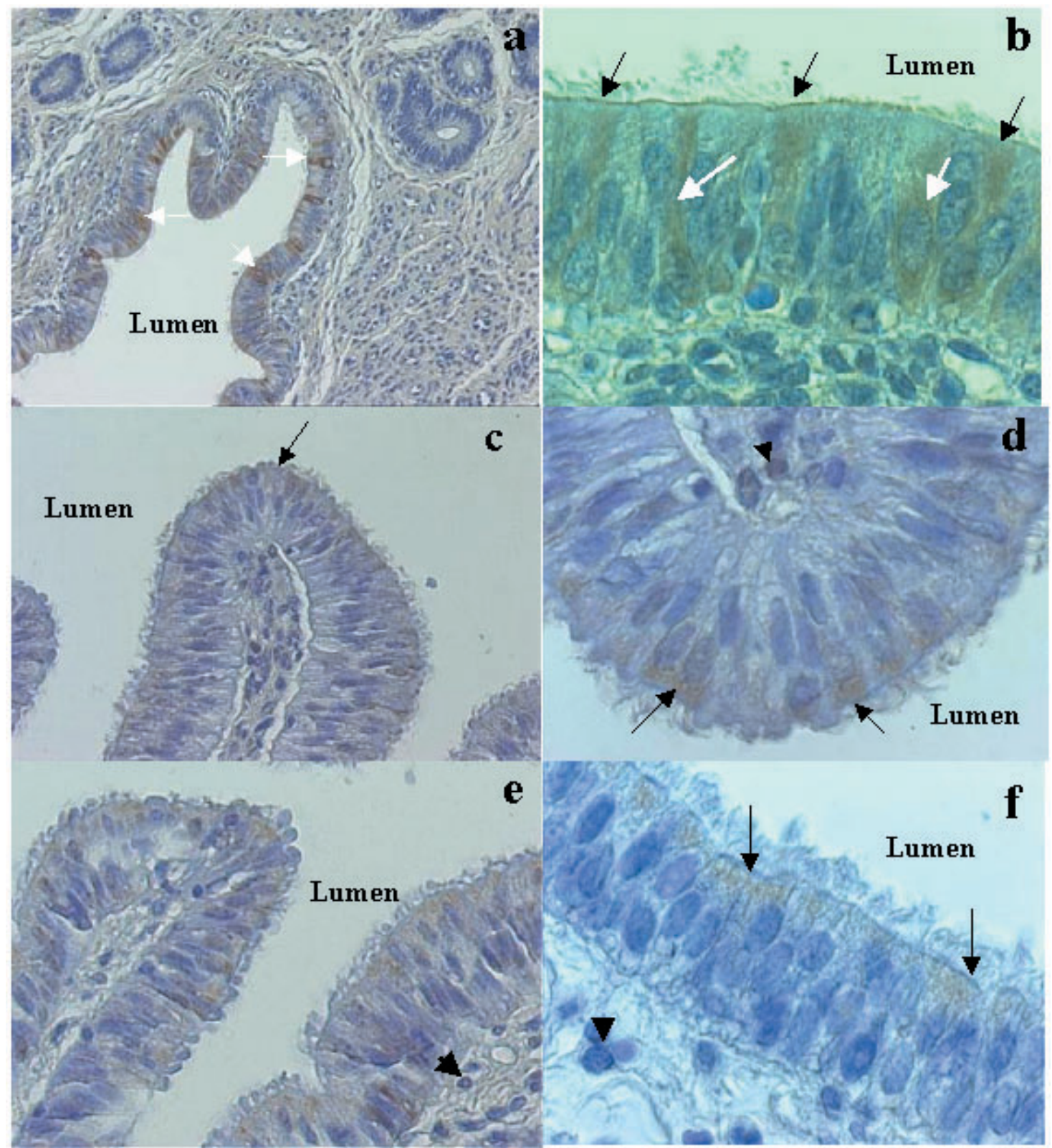

Fig. 2a-f. Immunolabelling for CD44 in the bovine oviduct. Microphotographs of the bovine oviduct (a-b: UTJ in metoestrus, c-d: isthmus in oestrus, e-f: ampulla in dioestrus; a: $\times 100$, c and e: $\times 200, b, d$, and $\mathrm{f}: \times 600$ ). The slides are counterstained with haematoxylin. Black arrows depict positive CD44-staining in the epithelial ad-luminal surface as well as in the supra-nuclear region of scattered epithelial cells, either ciliated or secretory. White arrows show positive staining in the whole cytoplasm of UTJ-epithelial cells. Black arrowheads show positive staining in leukocyte-like cells.

different CD44 protein expressions, where isoforms differ both in amino acid sequence and carbohydrate composition. The glycosylation of CD44 is tissue-specific and important for HA binding $[12,51,52]$. Variations in the degree of glycosylation could give rise to multiple molecular weights in the range of 180-200 kDa [53]. The molecular weight $(200 \mathrm{kDa})$ of the protein found in the epithelial homogenates from the UTJ segment is the same as that reported for a similar protein from 


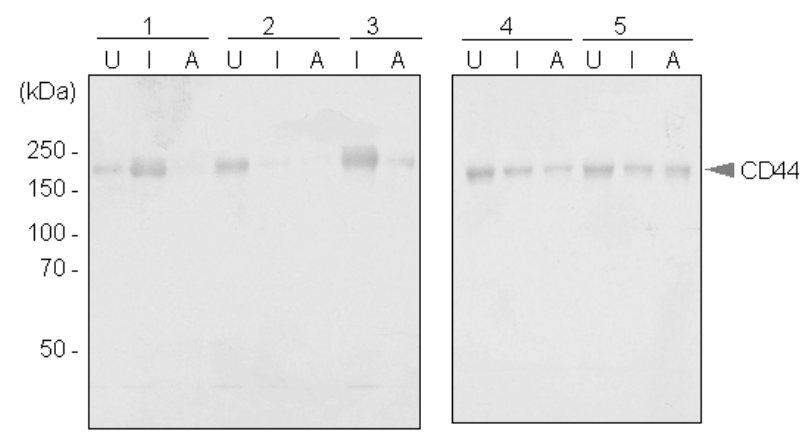

Fig. 3. Western blot probed with anti-mouse CD44 (KM201) on epithelial cell homogenates collected from the A (ampullar), I (isthmic), and U (UTJ) segments of the oviducts from five SRB-heifers in standing oestrus.

the epithelium of the porcine oviduct [45]. Terpe $e t$ al. [54] reported that CD44 variant isoforms are mostly restricted to basal and luminal epithelia of human endometrium, while another study detected an epithelial isoform of CD44 in the human endometrium with an approximate molecular mass of $130 \mathrm{kDa}$ [17]. The CD44 in the oviductal epithelium may be a CD44 variant form, ligating $\mathrm{HA}$ to $\mathrm{CD} 44$.

The turnover of HA occurs systematically from the lymph serum as well as locally aided by the same cells responsible for its synthesis. CD44 also participates in the uptake and degradation of HA [15]. The CD44 receptor does not have a hyaluronidase activity in itself; but rather mediates the uptake of HA into the cell where it can be degraded by acid hydrolases in lysosomes [9]. The particular localization of the CD44 in the epithelial cells of the bovine oviduct, specifically, in the supra-nuclear cytoplasm, may reflect the involvement of CD44 in the local uptake and degradation of HA from the bovine oviductal fluid [2]. CD44 could ligate HA at the surface of the cell, hence the positive immunolabeling on the apical surface of the cells, then internalize HA into the cell by a phagocytotic mechanism where the HA is degraded. A perfect match between supra-nuclear CD44 location and lysosomal phosphatase staining has previously been reported in this laboratory [45]. The presence of CD44 in the cytoplasm of the tubal epithelial cells could also represent the intracellular domain of CD44, thus providing a direct association with signalling between $\mathrm{HA}$ and the cytoskeleton proteins [22]. In a recently published study [55], the authors were unable to detect CD44 in the bovine oviductal epithelium through immunohistochemistry, although they detected CD44 mRNA in bovine oviductal tissue. The reason for the conflicting results might be the use of different antibodies and the several different isoforms of CD44 that exist.

The CD44 protein has been found by immunohistochemistry in a variety of mammalian epithelial cells, including those lining the oviduct, uterus, and vagina [1]. During mammalian embryonic development, both HA and CD44 seem to play an important role in the pre-implantation embryo [23], and in throphoblast remodeling of the placenta [20-22]. The CD44 membrane protein has also been observed on a wide variety of cells including lymphocytes, monocytes, granulocytes, erythrocytes, fibroblasts, and epithelial cells [4]. Besides the presence of CD44 in the oviductal epithelial cells, we could also detect positive immunolabelling in the tubal connective tissue, especially in the lamina propria of the ampulla segment, which contains more connective tissue than the other segments of the organ. This is in accordance with previous results where CD44 has been found constitutively in most cells of connective tissue, as well as some proliferative epithelial cells [1]. An expected, CD44 immunostaining was present in the leukocyte-like cells in our oviductal sections, as well as in bovine leukocytes in positive control smears, thus confirming the general specificity of the antibodies.

In the present study of the bovine oviduct collected from well-defined oestrous cycle stages, we could not detect any significant differences in terms of immunohistochemical localization of CD44 in the tubal epithelium along the oestrous cycle. Such general pattern of consistent immunoreactivity was also found in human endometrium along the normal menstrual cycle [17]. However, another study, also of women, detected cycle-dependent CD44 regulation in normal endometrium $[18,25]$ have suggested an endocrine influence on the mRNA expression of CD44, proposing the presence of a local communication between the cumulus-derived HA and the HA receptors on the reproductive epithelium of the bovine oviduct. Considering the source and typing of tissues varied considerably, further research in this area is needed before final assertions can be made.

Hyaluronan is supposed to play a fundamental 
role during sperm capacitation and fertilization in cattle $[24,25,39]$. Distribution of HA with respect to the role of sperm hyaluronidase in sperm penetration and gamete interaction is well established. Investigators have been able to detect the presence of a $68-\mathrm{kDa}$ cell surface hyaluronic acid binding glycoprotein (HABP) in the spermatozoa of rats, mice, bulls, and humans. They also observed that HABP was involved in phosphorylation in motile spermatozoa in vivo [31]. Another study found that a lower level of HABP in human spermatozoa was associated with decreased motility [56].

Considering the bulk of information available and the present results, the localization of CD44 in the functional sperm reservoir of cattle indicates that there may be a CD44-HA pathway in this segment of the bovine oviduct which could play a role in oocyte maturation, sperm storage, capacitation, and possibly other interactions before fertilization. Such an interaction may be between the HA of the cumulus-oocyte complexes, or the follicular fluid, and the CD44 in the oviduct. We also speculate that the CD44 receptor may be involved in the binding of spermatozoa to the oviductal epithelial cells during their storage in the sperm reservoir. Another hypothesis is that the CD44, in the oviductal epithelium, provides the oviduct with fresh HA continuously, and this HA is needed either for prolongation of the sperm survival, to prevent capacitation, or to protect the spermatozoa resting in the reservoir from detection by the female immune response. Such hypotheses need to be tested, so further investigation is warranted.

\section{Acknowledgements}

We would like to thank Ms Åsa Jansson for her technical assistance. Funding was provided by FORMAS (formerly the Swedish Council for Forestry and Agricultural Research-SJFR), by the Swedish Foundation for International Cooperation in Research and Higher Education (STINT), and by the SLU-Japan Programme on Reproductive Biotechnology, Stockholm.

\section{References}

1. Alho AM, Underhill CB. The hyaluronate receptor is preferentially expressed on proliferating epithelial cells. J Cell Biol 1989; 108: 1557-1565.

2. Lee CN, Ax RL. Concentrations and compositions of glycosaminoglycans in the bovine female reproductive tract. J Dairy Sci 1984; 67: 2006-2009.

3. Toole BP. Hyaluronan and its binding proteins, the hyaladherins. Curr Opin Cell Biol 1990; 2: 839-844.

4. Underhill C. CD44: the hyaluronan receptor. J Cell Sci 1992; 103: 292-298.

5. Turley EA. Hyaluronan and cell locomotion. Cancer Metastasis Rev 1992; 11: 21-30.

6. Hunnicutt GR, Primakoff P, Myles DG. Sperm surface protein $\mathrm{PH}-20$ is bifunctional: one activity is a hyaluronidase and a second, distinct activity is required in secondary sperm-zona binding. Biol Reprod 1996; 55: 80-86.

7. Aruffo A, Stamenkovic I, Melnick M, Underhill CB, Seed B. CD44 is the principal cell surface receptor for hyaluronate. Cell 1990; 61: 1303-1313.

8. Ponta H, Wianwright D, Herrlich P. The CD44 protein family. J Biochem Cell Biol 1998; 30: 299-305.

9. Culty $\mathbf{M}$, Nguyen HA, Underhill CB. The hyaluronan receptor (CD44) participates in the uptake and degradation of hyaluronan. J Cell Biol
1992; 116: 1055-1062.

10. Thomas L, Byers HR, Vink J, Stamenkovic I. $\mathrm{CD} 44 \mathrm{H}$ regulates tumor cell migration on hyaluronate-coated substrate. J Cell Biol 1992; 118: 971-977.

11. Woerner SM, Givehchian M, Durst M, Schneider A, Costa S, Melsheimer P, Lacroix J, Zoller M, Doeberitz MK. Expression of CD44 splice variants in normal, dysplastic, and neoplastic cervical epithelium. Clin Cancer Res 1995; 1: 1125-1132.

12. Borland G, Ross JA, Guy K. Forms and functions of CD44. Immunol 1998; 93: 139-148.

13. Saegusa M, Hashimura M, Okayasu I. CD44 expression in normal, hyperplastic, and malignant endometrium. J Pathol 1998; 184: 297-306.

14. Kaneko T, Saito H, Toya M, Satio T, Nakahara K, Hiroi M. Hyalronic acid inhibits apoptosis in granulose cells via CD44. J Assist Reprod Genet 2000; 17: 162-167.

15. Knudson W, Chow G, Knudson CB. CD44mediated uptake and degradation of hyaluronan. Matrix Biol 2002; 21: 15-23.

16. Turley EA, Nobie PW, Bourguignon YW. Signalling properties of hyaluronan receptors. J Biol Chem 2002; 277: 4589-4592. 
17. Behzad F, Seif MW, Campbell S, Aplin JD. Expression of two isoforms of CD44 in human endometrium. Biol Reprod 1994; 51: 739-747.

18. Albers A, Thie M, Hohn HP, Denker HW. Differential expression and localization of integrins and CD44 in the membrane domains of human uterine epithelial cells during the menstrual cycle. Acta Anat 1995; 153: 12-19.

19. Ohta N, Saito H, Kaneko T, Yoshida M, Takahashi T, Saito T, Nakahara, K, Hiroi M. Soluble CD44 in human ovarian follicular fluid. J Assist Reprod Genet 2001; 18: 21-25.

20. Goshen R, Ariel I, Shuster S, Hochberg A, Vlodavsky I, de Groot N, Ben-Rafael Z, Stern R. Hyaluronan, CD44 and its variant exons in human trophoblast invasion and placental angiogenesis. Mol Hum Reprod 1996; 2: 685-691.

21. Aplin JD. Adhesion molecules in implantation. Rev Reprod 1997; 2: 84-93.

22. Marzioni D, Crescimanno C, Zaccheo D, Coppari R, Underhill CB, Castellucci M. Hyaluronate and CD44 expression in the human placenta throughout pregnancy. Eur J Histochem 2001; 45: 131-140.

23. Furnus CC, Valcarcel A, Dulout FN, Errecalde AL. The hyaluronic acid receptor (CD44) is expressed in bovine oocytes and early stage embryos Theriogenology 2003; 60: 1633-1644.

24. Ball GD, Bellin, ME Ax, RL, First NL. Glycosaminoglycans in bovine cumulus-oocyte complexes; morphology and chemistry. Mol Cell Endocrinol 1982; 28: 113-122.

25. Schoenfelder M, Einspanier R. Expression of hyaluronan synthases and corresponding hyaluronan receptors is differentially regulated during oocyte maturation in cattle. Biol Reprod 2003; 69: 269-277.

26. Kimura N, Konno Y, Miyoshi K, Matsumoto H, Sato E. Expression of hyaluronan synthases and CD44 messenger RNAs in porcine cumulus-oocyte complexes during in vitro maturation. Biol Reprod 2002; 66: 707-717.

27. Yokoo M, Miyahayashi $Y$, Naganuma T, Kimura N, Hiroshi S, Sato E. Identification of hyaluronic acid-binding proteins and their expression in porcine cumulus-oocyte complexes during in vitro maturation. Biol Reprod 2002; 67: 1165-1171.

28. Yokoo M, Tienthai P, Kimura N, Niwa K, Sato E, Rodriguez-Martinez $\mathbf{H}$. Localisation of the hyaluronan receptor CD44 in porcine cumulus cells during in vivo and in vitro maturation. Zygote 2002; 10: 317-326.

29. Eppig JJ. FSH stimulates hyaluronic acid synthesis by oocyte-cumulus cell complexes from mouse preovulatory follicles. Nature 1979; 281: 483-484.

30. Ohta N, Sairo H, Kuzumkai T, Takahashi T, Ito NM, Saito T, Nakahara K, Hiroi M. Expression of CD44 in human cumulus and mural granulosa cells of individual patients in in-vitro fertilization programmes. Mol Hum Reprod 1999; 5: 22-28.

31. Ranganathan S, Ganguly AK, Datta K. Evidence for presence of hyaluronan binding protein on spermatozoa and its possible involvement in sperm function. Mol Reprod Dev 1994; 38: 69-76.

32. Hunter RH. The Fallopian tubes: their role in fertility and infertility. In: The Fallopian Tubes, Chapter IV. New York: Springer-Verlag, 1988; 5374.

33. Hunter RH, Flechon B, Flechon JE. Distribution, morphology and epithelial interactions of bovine spermatozoa in the oviduct before and after ovulation: a scanning electron microscope study. Tissue Cell 1991; 23: 641-656.

34. Lefebvre R, Chenoweth PJ, Drost M, LeClear CT, MacCubbin M, Dutton JT, Suarez SS. Characterization of the oviductal sperm reservoir in cattle. Biol Reprod 1995; 53: 1066-1074.

35. Pollard JW, Plante C, King WA, Hansen PJ, Betteridge KJ, Suarez SS. Fertilizing capacity of bovine sperm may be maintained by binding to oviductal epithelial cells. Biol Reprod 1991; 44: 102107.

36. Lefebvre R, Suarez SS. Effect of capacitation on bull sperm binding to homologous oviductal epithelium. Biol Reprod 1996; 54: 575-582.

37. Fazeli A, Duncan AE, Watson PF, Holt WV. Sperm-oviduct interaction: induction of capacitation and preferential binding of uncapacitated spermatozoa to oviductal epithelial cells in porcine species. Biol Reprod 1999; 60: 879-886.

38. Rodriguez-Martinez H, Tienthai P, Suzuki K, Funahashi H, Ekwall H, Johannisson A. Involvement of oviduct in sperm capacitation and oocyte development in pigs. Reproduction 200; 58 (suppl): 129-145.

39. Parrish JJ, Susko-Parrish JL, Handrow RR, Sims MM, First ML. Capacitation of bovine spermatozoa by oviduct fluid. Biol Reprod 1989; 40: 1020-1025.

40. Huszar G, Willetts M, Corrales M. Hyaluronic acid (Sperm Select) improves retention of sperm motility and velocity in normospermic and oligospermic specimens. Fertil Steril 1990; 54: 1127-1134.

41. Kawakami E, Hori T, Tsutsui T. Induction of dog sperm capacitation by oviductal fluid. J Vet Med Sci 1998; 60: 197-202.

42. Suzuki K, Asano A, Eriksson B, Niwa K, Nagai T, Rodriguez-Martinez $\mathbf{H}$. Capacitation status and in vitro fertility of boar spermatozoa: effects of seminal plasma, cumulus-oocyte-complexes-conditioned medium and hyaluronan. Inter J Androl 2002; 25: 8493.

43. Bergqvist A-S, Rodríguez-Martínez H. Distribution of hyaluronan in the bovine oviduct. In: IETS Proceedings; 2003; Auckland, New Zeeland. Theriogenology 59; Abstract 467. 
44. Tienthai P, Kjellén L, Pertoft H, Suzuki K, Rodríguez-Martínez $\mathbf{H}$. Localization and quantitation of hyaluronan and sulphated glycosaminglycans in the tissues and intraluminal fluid of the pig oviduct. Reprod Fertil Develop 2000; 12: $173-182$.

45. Tienthai P, Yokoo M, Kimura N, Heldin P, Sato E, Rodriguez-Martinez H. Immunohistochemical localization and expression of the hyaluronan receptor CD44 in the epithelium of the pig oviduct during oestrus. Reproduction 2003; 13: 119-132.

46. Bains R, Adeghe J, Carson RJ. Human sperm cells express CD44. Fertil Steril 2002; 78: 307-312.

47. Duchens M, Rodriguez-Martinez H, Forsberg M, Gustafsson $\mathbf{H}$. Ultrastructure of bovine ovarian follicles induced to extended growth by perioestrous suprabasal progesterone levels. Acta Vet Scand 1996; 37: 239-250.

48. Hirano $\mathbf{H}$, Watanbe T. Microsequencing of protein electrotransferred onto immobilizing matrices from polyacrylamide gel electrophoresis; application of insoluble protein. Electrophor 1990; 11: 573-580.

49. Laurent C, Hellström S, Engström-Laurent A, Wells AF, Bergh A. Localization and quantity of hyaluronan in urogenital organs of male and female rats. Cell Tissue Res 1995; 279: 241-248.

50. Edelstam G, Lundkvist Ö, Wells A, Laurent T. Localization of hyaluronan in regions of the human female reproductive tract. I Histochem Cytochem 1991; 39: 1131-1135.

51. Stamenkovic I, Aruffo A, Amiot M, Seed B. The hematopoietic and epithelial forms of CD44 are distinct polypeptides with different adhesion potentials for hyaluronate-bearing cells. EMBO J 1991; 10: 343-348.

52. Bartolazzi A, Nocks A, Aruffo A, Spring F, Stamenkovic I. Glycosylation of CD44 is implicated in CD44-mediated cell adhesion to hyaluronan. J Cell Biol 1996; 1322: 1199-1208.

53. Jalkanen S, Jalkanen $\mathbf{M}$, Bargatze $\mathbf{R}$, Tammi $\mathbf{M}$, Butcher EC. Biochemical properties of glycoproteins involved in lymphocyte recognition of high endothelial venules in man. J Immunol 1988; 141: 1615-1623.

54. Terpe HJ, Stark H, Prehm P, Gunthert U. CD44 variant isoforms are preferentially expressed in basal epithelial of non-malignant human fetal and adult tissues. Histochem 1994; 101: 79-89.

55. Ulbrich SE, Schoenfelder M, Thoene S, Einspanier R. Hyaluronan in the bovine oviduct-modulation of synthases and receptors during the estrous cycle. Mol Cell Endocrin 2004; 214: 9-18.

56. Ghosh I, Bharadwaj A, Datta K. Reduction in the level of hyaluronan binding protein 1 (HABP1) is associated with loss of sperm motility. I Reprod Immunol 2002; 53: 45-54. 